\title{
Evaluation of Food and Nutrition Security Level at Provincial Level Based on Outcome Indicators in Indonesia
}

\author{
Andra Vidyarini ${ }^{*}$, Drajat Martianto ${ }^{2}$, Hidayat Syarief ${ }^{2}$ \\ ${ }^{1}$ Program Study of Nutrition Science, Faculty of Health Sciences, Prof. Dr. Hamka Muhammadiyah \\ University, South Jakarta 12210, Indonesia \\ ${ }^{2}$ Department of Community Nutrition, Faculty of Human Ecology, IPB University, \\ Bogor 16680, Indonesia
}

\begin{abstract}
This study aims at evaluating the situation of Food and Nutrition Security (FNS) at provincial level using six outcome indicators. The cross-sectional study, utilized secondary data from 33 provinces published in 2013. It used a modification of the Global Hunger Index (GHI) method and changed the number of outcome indicators. In addition, an equalization was performed, so that the results obtained were positive. The results showed that all provinces in Indonesia have moderate or less secure food and nutrition level. Hence, the performance of the Indonesian government in food and nutrition security need to be improved. Bali Province had the highest rank in food and nutrition security, while East Nusa Tenggara and Papua Province had the lowest ranks of the 33 provinces during 2013. The low performance achievement of food and nutrition security based on the six outcome indicators signified by the high prevalence of the undernourished population and the high prevalence of stunting and wasting of children under five in all provinces in Indonesia.
\end{abstract}

Keywords: evaluation, food and nutrition security, outcome indicators

\section{INTRODUCTION}

Efforts to achieve food security have become a global concern because of its implications for economic and national resilience (FAO 2005; Godfray \& Garnett 2014; Maricic et al. 2016). In the last few decades, food security development has shown state of improvement in several countries in Asia and America, yet there are still gaps in several aspects, one of which is nutrition (FAO/IFAD/WFP 2014). Food insecurity and nutritional problems are interrelated in achieving food security; hence, it is necessary to integrate nutritional aspects in food security development (FAO 1996; Fanzo 2014; Keino et al. 2014; FAO 2012). The unachieved objective of food and nutrition security development in an area can be seen from the nutritional problems arising. For instance, the emergence of nutritional problems in vulnerable age groups such as stunting, underweight and micronutrient deficiency problems (Black et al. 2008; Ng et al. 2014; Bruce et al. 2004).

Currently, the efforts to address food and nutrition security in Indonesia have not been fully synergized with the efforts to improve nutrition status (BKP 2009). This can be seen from the persistent nutrition problems, such as stunting, wasting, low birthweight and others $(\mathrm{MoH}$ RI 2013a \& 2013b), despite the increasing trend in food availability (BKP 2015). The prevalence of stunting problems increased from 35.6 percent in 2010 to 37.2 percent in 2013 (MoH RI 2013b). The prevalence of wasting and undernourished has decreased from the previous year, but it is still relatively high, which is above 10 percent (MoH RI 2013a). It shows that the food and nutrition security program planned has not been implemented thoroughly due to various factors (Suryana et al. 2016).

Various measurement methods have been developed to evaluate the achievements of food and nutrition security development at the global level. The indicators developed at the global level can be modified for various purposes according to the level of evaluation of the achievement of food security and nutrition development based on the regional level (Santeramo 2015; Pangaribowo et al. 2013). In measuring the evaluation of the food and nutrition security level, Indonesia

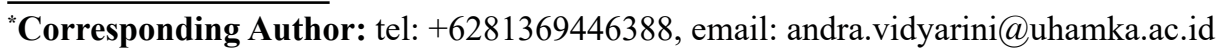


has developed one evaluation parameter and prioritization of programs in increasing food and nutrition security through the preparation of the Food Security and Vulnerability Atlas (FSVA) since 2005 (BKP 2009).

Evaluation of the food and nutrition security level based on outcome indicators can be used as a standard of development evaluation, and it is required in comparing assessments of food and nutrition security level. This evaluation can be carried out through inputs and through the results of programs or government policies (OECD 2008). This study aimed to evaluate the food and nutrition security level based on the achievement of outcome indicators at the provincial level in Indonesia. The results of this evaluation can be utilized to compare the rank of each province in their achievement on food and nutrition security development based on outcome indicators, as well as a refference for government evaluation in determining and implementing food and nutrition security development programs.

\section{METHODS}

\section{Design, location, and time}

The research was a descriptive, crosssectional study, utilizing secondary data. Data collection and processing were carried out from March to September 2017. Data processing was carried out at the IPB Univetsity, Bogor, West Java.

\section{Sampling}

The unit of analysis was 33 provinces. A province, North Kalimantan, was excluded in this study because it was not included in the Basic Health Research (RISKESDAS) 2013 since it was a newly formed province in 2012.

\section{Data collection}

In this study, the data utilized were nutritional and health status data published in 2012 and 2013. The selection of data publication year is based on the availability of the most recent data of RISKESDAS in 2013 and the latest mortality rate of under-five-year-old children in 2012. Research data was obtained through electronic data access and published reports from related agencies (Food Security Agency, Ministry of Agriculture of the Republic of Indonesia, Statistics Indonesia and Ministry of Health the Republic of Indonesia).

\section{Data analysis}

The preparation of the evaluation of food and nutrition security level was carried out in two stages, namely (1) identification and selection of indicators and (2) calculation of evaluation score and the evaluation of food and nutrition security levels. The initial stage in this study is the identification and selection of indicators. The identification and selection of prospective candidates for indicators are adjusted to the pillars of food and nutrition security, which are the pillars of availability, affordability and utilization. The identification of prospective outcome indicators used refers to the indicators used by FAO (2014), WHO (2015), RPJMN (BAPPENAS 2015) and KS-RANPG (DKP 2016) to produce 10 outcome indicators. Outcome indicators of food and nutrition security are indicators describing the long-term results of a program or activity related to food and nutrition security. Outcome indicators in food and nutrition security are indicated from nutrition status and public health problems in the community (FAO 2006).

The selection of indicators was carried out qualitatively based on several criteria; (1) according to the concept of food and nutrition security; (2) availability of data at the provincial level and not overlapping (redundant) between indicators. Qualitative selection of indicators resulted in six outcome indicators which are Percentage of undernourished population (PUN), Percentage of under-five-year-old children with stunting (CST), Percentage of under-five-yearold Children with wasting (CWA), Percentage of mortality rate on under-five-year-old children (CM), Percentage of infants with low birth weight $(<2,500 \mathrm{~g})(\mathrm{LBW})$, Percentage of pregnant women with Chronic Energy Deficiency (CED) (Upper Arm Circumference (UAC) is less than $23 \mathrm{~cm}$ ) (CED) (FAO (2014); WHO (2015); KSRANPG (DKP 2016))

The measurement of nutrition problems is carried out on under-five-year-old children because children in this age range are sensitive to changes in nutrition status. Hence, it can be utilized as an indicator in evaluating food and nutrition security. This led to the decision to utilize the prevalence rate of under-five-years-old children with stunting and wasting as indicators of food and nutrition programs achivement in the long run (DKP/Kementan/WFP 2015; Susanty \& Margawati 2012; Suryana et al. 2016). Stunting 
is a condition in which the child's height is too short for their age, measured for height for age with a value of below minus two standard deviations $(<-2 \mathrm{SD})$ based on the WHO definition (WHO 2010). Whereas, wasting is a condition where the child's weight based on their height is below minus two standard deviations $(<-2 \mathrm{SD})$ (WHO 2010). Apart from stunting and wasting in under-five-year-old children, the percentage of undernourished population also can be used to describe the nutrition status of the community at a broader age range. People experiencing undernourishement defined as citizens with a food consumption of less than $70 \%$ of the RDA (less than 1,470 kcal) per day.

In this study, the method utilized was modified from the Global Hunger Index (GHI) method. GHI arranged by the International Food Policy Research Institute (IFPRI) is a measurement tool for assessing food and nutrition security, especially hunger. The GHI method combines indicators of nutrition and health problems and describes the nutritional situation in the pupolation, especially children, as sensitive age group to changing nutrient intake such as energy, protein and other micronutrients (von Grebmer et al. 2017). The GHI employs four indicators and does not equalize the final value, while the method used in this study modified it by using six selected indicators, changing the calculation methods, and employing a value equalization (all indicators are positive for food and nutrition security).

The succeeding stage of this research is the calculation of the index value. The steps undertaken in calculating the index value are: (1) standardization of the indicator value; (2) calculation of the total provincial evaluation score; (3) equalization of the total score; (4) evaluation of the provincial food and nutrition security level based on the evaluation score: (1) Standardization of the indicator values. Standardization of the indicator value is performed by multiplying the actual value by the maximum value of each indicator in percentage units. The maximum value of the indicator is the rounding off of the highest value for each indicator. The examples of standardization of indicator values are as follows: The prevalence of actual value for stunting in under-five-year-old children is 32 percent, and the highest value for the prevalence of stunting for under-five-year-old children is 51.7 percent (rounded to 60 percent). Accordingly, the standardized indicator value for under-five-year-old children with stunting is $32 / 60 \times 100=53$; (2) Calculation of the total provincial evaluation score. The formulation used to calculate the total score in this study is a modification of the formula for calculating the index of GHI. The formulas used are:

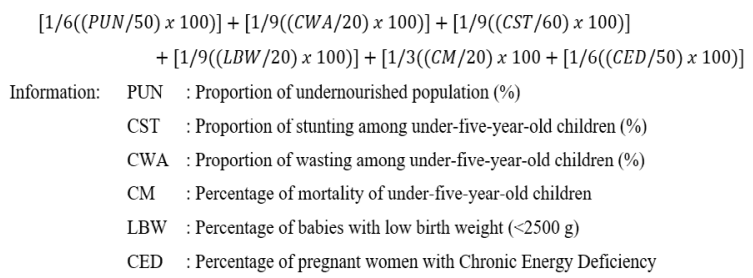

(3) Equalization of the total score. The value or evaluation score obtained is subjected to an equalization, so that it has a positive effect on food and nutrition security. The equalization is carried out using the formula 100-a, where $\mathrm{a}$ is the total evaluation score for each province (in stage 2); (4) Evaluation of food and nutrition security level at provincial level. The scale of evaluation score in this study ranged from 0 to 100 , where the higher the score, the ideal conditions will be established. The value of 100 illustrates the food and nutrition security level at the provincial level are good where the province does not have an undernourished population; there are no underfive-year-old children who are stunted and wasted; there are no deaths among under-five-year-old children; and there are no pregnant women who suffered from chronic energy deficiencies, as well as there are no infants born with low weight (under 2,500 g). If a province has a value close to 0 , it illustrates the opposite (IFPRI 2014). After the score is obtained, it is categorized based on the cut off point. Determination of the cut off value for the outcome indicator refers to the planning document or standard set by the The Ministry of Health (MoH RI 2002), and NLISWHO (2010) for indicators of nutrition status. The categorization of the food and nutrition security level were divided into four categories which are high $(\geq 77.41)$, moderate (77.41-58.33), low $(58.33-35.92)$ and very low $(\leq 35.92)$. The total evaluation score shows that the higher the evaluation score, the better the food and nutrition security level of a province. The determination of the cut off point employed the same method as the calculation of the evaluation score, but it uses 
the ideal number set by the Ministry of Health Republic of Indonesia (2002), and NLIS-WHO (2010). Processing and data analysis in this study were done using Microsoft Excel 2007.

\section{RESULTS AND DISCUSSION}

\section{Situation of food and nutrition security based on outcome indicators}

Nutrition problems, morbidity and mortality rates reflect problems that exist in a country ranging from the level of availability and access of food to environmental health and individual health status. In this study, the outcome indicators used indicators of nutrition problems, morbidity and mortality, namely the proportion of undernourished people, the percentage of under-five-year-old children with wasting, the percentage of under-five-year-old children with stunting, the percentage of mortality rates of under-five-year-old children, the percentage of infants with Low Birth Weight (LBW) and the percentage of pregnant women with Chronic Energy Deficiency (CED) (Table 1).

The percentage of under-five-year-old children experiencing stunting and wasting is one of the globally recognized indicators used to assess the food and nutrition security level in a region. It is because stunting and wasting are nutritional problems influenced by various factors related to food, sanitation, and infectious diseases or health. The low level of household socio economic status which hinder the family access in meeting the need for quality food is also one of the causes of the high rate of stunting in the community (Ulfani et al. 2011).

Based on the data (Table 1), Province of Riau Islands had the lowest stunting rate of under-five-year-old children (26.3\%) when compared to other provinces. Whereas, NTT had the highest prevalence of under-five-year-old children $(51.7 \%)$. Based on the category of underfive-year-old children with wasting, Province of Bali (8.8\%) had the lowest percentage, while the Province of West Kalimantan $(18.7 \%)$ had the highest percentage compared to other provinces.

Apart from stunting and wasting, the percentage of undernourished population is an outcome indicator that can be used in evaluating the food and nutrition security level. FAO (2015) states that the undernourished population is closely related to the existence of gaps in meeting their food needs in the long term, thus will affect their nutrition status. Based on the percentage of undernourished population indicators, DIY and Bali provinces had the lowest proportion of undernourished population, while Papua and West Papua had the highest proportion.

The provinces of Riau, North Sumatra and Bali had the lowest percentages based on indicators of mortality among under-five-yearold children, infants with low birth weight and pregnant women with CED, while Papua province had the highest percentages for indicators of mortality rates of under-five-year-old children and pregnant women with CED. In addition, Central Sulawesi had the highest percentage of infants with low birth weight.

Based on the outcome indicator data, the eastern part of Indonesia had the highest prevalence in almost all indicators. It shows the eastern part of Indonesia is lacking in quality of health compared to the other parts of Indonesia. The low quality of health in the eastern region this could be due to the lack of public awareness of the importance of maintaining environmental health and food quality (Tono et al. 2016).

\section{Evaluation of food and nutrition security level based on the outcome indicators}

The food and nutrition security level based on the outcome indicators can be used as an evaluation tools to measure the success of government programs in developing food security and to improve nutrition status (Suryana et al. 2016). Outcome indicators, generally described as impaired physical growth and cognitive development of under-five-year-old children (under-five-year-old children with stunting and wasting), are indirect indicators of food security (UNICEF 1992).

Based on the results of the calculation of the evaluation score on the food security level based on the 2013 outcome indicators, all provinces $(100 \%)$ in Indonesia fall into the medium and low categories. It shows that the food and nutrition security level based on outcomes indicators in Indonesia is still sub optimal, hence the local government efforts in developing food security and nutrition must be improved, especially in dealing with food and nutrition problems. Nationally, the low level of food and nutrition security can be seen from the fact that there are still nutrition problems in all provinces 
FNS evaluation based on outcome indicators in Indonesia

Table 1. Outcome indicators by province in Indonesia 2013

\begin{tabular}{|c|c|c|c|c|c|c|}
\hline Province & PUN (\%) & CWA $(\%)$ & CST $(\%)$ & CM (\%) & LBW (\%) & CED (\%) \\
\hline Aceh & 20.5 & 15.7 & 41.5 & 5.2 & 8.6 & 20.3 \\
\hline North Sumatra & 20.8 & 14.9 & 42.5 & 5.4 & 7.2 & 17.1 \\
\hline West Sumatra & 15.4 & 12.6 & 39.2 & 3.4 & 7.3 & 17.8 \\
\hline Riau & 18.7 & 15.6 & 36.8 & 2.8 & 8.6 & 23.5 \\
\hline Jambi & 23.9 & 13.5 & 37.9 & 3.6 & 8.2 & 23.0 \\
\hline South Sumatra & 17.5 & 12.3 & 36.7 & 3.7 & 9.3 & 21.1 \\
\hline Bengkulu & 16.2 & 14.8 & 39.7 & 3.5 & 9.7 & 23.7 \\
\hline Lampung & 20.5 & 11.8 & 42.6 & 3.8 & 8.0 & 21.3 \\
\hline Bangka Belitung & 19.8 & 10.2 & 28.7 & 3.2 & 9.4 & 21.2 \\
\hline Riau Islands & 20.0 & 12.3 & 26.3 & 4.2 & 9.2 & 25.4 \\
\hline DKI Jakarta & 18.2 & 10.2 & 27.5 & 3.1 & 9.3 & 17.6 \\
\hline West Java & 18.9 & 10.9 & 35.3 & 3.8 & 10.8 & 21.6 \\
\hline Central Java & 17.8 & 11.1 & 36.7 & 3.8 & 9.7 & 23.2 \\
\hline DI Yogyakarta & 5.2 & 9.4 & 27.3 & 3.0 & 9.4 & 22.6 \\
\hline East Java & 18.4 & 11.4 & 35.8 & 3.4 & 11.2 & 29.8 \\
\hline Banten & 12.7 & 13.8 & 33.0 & 3.8 & 9.7 & 27.4 \\
\hline Bali & 6.9 & 8.8 & 32.6 & 3.3 & 8.8 & 10.1 \\
\hline West Nusa Tenggara & 9.3 & 11.9 & 45.2 & 7.5 & 12.2 & 19.1 \\
\hline East Nusa Tenggara & 27.4 & 15.5 & 51.7 & 5.8 & 15.5 & 45.5 \\
\hline West Kalimantan & 20.6 & 18.7 & 38.6 & 3.7 & 14.4 & 29.7 \\
\hline Central Kalimantan & 18.6 & 12.4 & 41.3 & 5.6 & 13.7 & 21.6 \\
\hline South Kalimantan & 14.7 & 12.8 & 44.2 & 5.7 & 10.1 & 27.4 \\
\hline East Kalimantan & 29.9 & 11.6 & 27.6 & 3.1 & 10.8 & 27.5 \\
\hline North Sulawesi & 17.3 & 9.9 & 34.8 & 3.7 & 8.0 & 22.6 \\
\hline Central Sulawesi & 19.7 & 9.4 & 41.0 & 8.5 & 16.8 & 32.6 \\
\hline South Sulawesi & 17.2 & 11.0 & 40.9 & 3.7 & 12.4 & 31.2 \\
\hline North Sulawesi & 21.0 & 11.4 & 42.6 & 5.5 & 9.4 & 23.5 \\
\hline Gorontalo & 25.1 & 11.7 & 38.9 & 7.8 & 13.2 & 18.5 \\
\hline West Sulawesi & 15.5 & 48.0 & 10.8 & 7.0 & 11.9 & 20.2 \\
\hline Maluku & 31.0 & 16.2 & 40.6 & 7.0 & 11.1 & 34.3 \\
\hline North Maluku & 35.9 & 12.2 & 41.1 & 6.0 & 11.6 & 24.7 \\
\hline West Papua & 36.1 & 15.4 & 44.7 & 8.5 & 11.0 & 25.1 \\
\hline Papua & 41.0 & 14.8 & 40.1 & 10.9 & 15.6 & 37.2 \\
\hline Indonesia & 18.7 & 12.1 & 37.2 & 11.5 & 10.2 & 24.2 \\
\hline \multicolumn{7}{|c|}{ Source: BKP (2016); MoH RI (2012; 2013a; 2013b) } \\
\hline \multicolumn{7}{|c|}{ PUN: Proportion of undernourished population (\%) } \\
\hline \multicolumn{7}{|c|}{ CST: Proportion of stunting among under-five-year-old children (\%) } \\
\hline \multicolumn{7}{|c|}{ CWA: Proportion of wasting among under-five-year-old children (\%) } \\
\hline \multicolumn{7}{|c|}{ CM Percentages of mortality of under-five-year-old children } \\
\hline \multicolumn{7}{|c|}{ LBW: Percentages of babies with low birth weight $(<2,500 \mathrm{~g})$} \\
\hline CED: Percentages of pre & at women wit & hronic Energ & & & & \\
\hline
\end{tabular}


in Indonesia (Table 2), such as undernourished population and pregnant women with chronic energy deficiency, under-five-year-old children with stunting, wasting and infants with Low Birth Weight (LBW). Moreover, the mortality in under-five-year-old children is also high.

The analysis results showed Bali province had the highest score, and Papua had the lowest score compared to other provinces. It is in line with the results of the Food Security and Vulnerability Atlas (FSVA) 2015, where the province of Bali had no food insecure areas, and Papua has the highest priority areas for food insecurity compared to other provinces (BKP 2015). The rank of evaluation score for the food and nutrition security level based on the outcome of each province are prsesnted in Table 2.

Based on the table above, the provinces of Bali, DI Yogyakarta and DKI Jakarta had the highest scores indicating that the food and nutrition security level based on outcome indicators is better than other provinces. It can be seen from the low prevalence of undernourished population, pregnant women with Chronic Energy Deficiency (CED) and the low rates of under-five-year-old children with stunting and wasting. The food and nutrition security level in these three provinces are also indicated by the low percentage of infants with LBW in 2013. This condition could be due to better access to adequate health service and food availability so that nutrition problems are lower than in other provinces. This condition will trigger a low mortality rate for infants and under-five-year-old children, so that the ultimate goal of developing food and nutrition security can be achieved, which is to create better quality of active and competitive human resources especially in development country (Suryana et al. 2016).

The provinces of West Papua, NTT and Papua had the lowest evaluation scores compared to other provinces. The low level of food and nutrition security based on the outcome indicators of the three provinces can be influenced by the high proportion of undernourished people, pregnant women with chronic energy deficiency and other health problems in babies and underfive-year-old children (stunting, wasting, LBW and mortality rate). In addition, the high score of NTT province is due to the fact that many areas are categorized as vulnerable and highly vulnerable due to the low level of public health quality (lack of sanitation and access to clean water) (Tono et al. 2016). The results of this study are consistent with the research conducted by Ismail et al. (2016) where the implementation of nutrition programs in Papua and West Papua has not been optimal and is running according to the planned program.

Based on the results of the FSVA 2015, the provinces of Papua, West Papua and East Nusa Tenggara are included in the priority areas for food insecurity and none of the provinces are categorized as food secure. It is in accordance with the results obtained in this study. The high rates of stunting, wasting and undernourished in West Papua, East Nusa Tenggara and Papua are influenced by the low quality and less variety of food consumed by the community and the lack of socialization about the importance of health in the community (BKP 2009). In addition, the level of hunger or chronic lack of energy in pregnant women can cause nutrition problems e.g infants with low birth weight (Warsini et al. 2016). This then leads to stunting during future growth (Supriyanto et al. 2018). It is in line with the research conducted by Palupi et al. (2013) where stunting, wasting and undernourished are influenced by low levels of energy and protein intake in individuals, both children and adult.

The results of this study indicated that food and nutrition security in Indonesia, especially based on the outcome indicators, should receive more attention from the government, especially in eastern part of Indonesia. According to Nurhemi et al. (2014), western part of Indonesia as a whole has better conditions than other regions due to infrastructure support and the support of public awareness on food and nutrition security when compared to other regions, especially in eastern part of Indonesia. Thus, the results indicated that there is a need to improve nutrition sensitive and specific programs implementation, so that the goals of developing food and nutrition security in equitable manner in Indonesia can be achieved.

\section{CONCLUSION}

Evaluation of the food and nutrition security level based on outcome indicators was carried out using six indicators employing a method modified from the GHI. Based on the evaluation of the food and nutrition security level outcome indicators, all provinces in Indonesia 
FNS evaluation based on outcome indicators in Indonesia

Table 2. Evaluation scores and food and nutrition security levels based on outcome indicators

\begin{tabular}{|c|c|c|c|}
\hline No & Province & Score & Category \\
\hline 1 & Bali & 73.02 & Moderate \\
\hline 2 & DI Yogyakarta & 70.24 & Moderate \\
\hline 3 & Jakarta & 66.98 & Moderate \\
\hline 4 & West Sumatra & 64.96 & Moderate \\
\hline 5 & Bangka Belitung & 64.81 & Moderate \\
\hline 6 & North Sulawesi & 64.16 & Moderate \\
\hline 7 & South Sumatra & 62.16 & Moderate \\
\hline 8 & Central Java & 61.67 & Moderate \\
\hline 9 & West Java & 61.58 & Moderate \\
\hline 10 & Banten & 61.14 & Moderate \\
\hline 11 & Riau Islands & 61.04 & Moderate \\
\hline 12 & Riau & 61.01 & Moderate \\
\hline 13 & Lampung & 60.83 & Moderate \\
\hline 14 & Bengkulu & 59.91 & Moderate \\
\hline 15 & Jambi & 59.30 & Moderate \\
\hline 16 & East java & 59.09 & Moderate \\
\hline 17 & North Sumatra & 58.22 & Low \\
\hline 18 & East Kalimantan & 58.14 & Low \\
\hline 19 & South Sulawesi & 57.14 & Low \\
\hline 20 & North Sulawesi & 56.56 & Low \\
\hline 21 & Aceh & 56.55 & Low \\
\hline 22 & West Nusa Tenggara & 56.29 & Low \\
\hline 23 & South Kalimantan & 55.56 & Low \\
\hline 24 & Central Kalimantan & 55.11 & Low \\
\hline 25 & West Sulawesi & 54.93 & Low \\
\hline 26 & West Kalimantan & 51.54 & Low \\
\hline 27 & Gorontalo & 51.43 & Low \\
\hline 28 & North Maluku & 48.98 & Low \\
\hline 29 & Central Sulawesi & 46.26 & Low \\
\hline 30 & Maluku & 43.87 & Low \\
\hline 31 & West Papua & 42.48 & Low \\
\hline 32 & East Nusa Tenggara & 39.22 & Low \\
\hline \multirow[t]{2}{*}{33} & Papua & 31.44 & Very Low \\
\hline & Indonesia & 47.26 & Moderate \\
\hline
\end{tabular}


$(100 \%)$ have a low level of food security. It shows Indonesia still has a fairly high level of nutrition problems, where the higher the evaluation value, the better the evaluation of food and nutrition security level of the province. The provinces of Bali, DI Yogyakarta and DKI Jakarta achieved the highest food and nutrition security levels, while the provinces of West Papua, East Nusa Tenggara and Papua were the lowest in food and nutrition security levels compared to other provinces. It shows that nutrition programs implementation in increasing food and nutrition security, must be improved in all regions of Indonesia, and prioritized on the eastern part of Indonesia. Based on the results of this study, more attention should be put on programs to improve nutritional problems, such as stunting, wasting, reducing mortality rate of under-five-year-old children, reducing the number of pregnant women with CED and alleviating undernourished population. Underlying factors leading to food insecurity in certain areas mentioned need to also be evaluated in future studies.

\section{ACKNOWLEDGEMENT}

We thank to Food Security Agency, Ministry of Agriculture of the Republic of Indonesia, Statistics Indonesia and Ministry of Health the Republic of Indonesia for the access of data in this research.

\section{AUTHOR DISCLOSURES}

The authors have no conflict of interest.

\section{REFERENCES}

[BAPPENAS] Badan Perencanaan Pembangunan Nasional. 2015. Rencana Pembangunan Menengah Nasional Tahun 2015-2019. Jakarta (ID): Bappenas.

[BKP] Badan Ketahanan Pangan. 2015. Kajian Kerawanan Pangan Nasional, Kerjasama BKP dan BPS. Jakarta (ID): Kementan RI

[BKP] Badan Ketahanan Pangan. 2009. Peta Kerentanan dan Ketahanan Pangan Tahun 2009. Jakarta (ID): DKP dan WFP

Black RE, Allen LH, Bhutta ZA, Caulfield LE, de Onis M, Ezzati M, Mathers C, Rivera J. 2008. Maternal and child undernutrition: Global and regional exposures and health consequences. Lancet 371(9608):243-260. https://doi.org/10.1016/S 0140 6736(07)61690-0.

Bruce Furness BW, Simon PA, World Cm, Asarian-Anderson J. 2004. Prevalence and predictors of food insecurity among low-income households in Los Angeles County. Public Health Nutr 7(6):791-794. https://doi.org/10.1079/PHN2004608.

[DKP] Dewan Ketahanan Pangan. 2016. Kebijakan Strategis dan Rencana Aksi Nasional Pangan dan Gizi 2016-2019. Jakarta (ID): Dewan Ketahanan Pangan

[DKP/Kementan/WFP] Dewan Ketahanan Pangan, Kementerian Pertanian, Word Food Programme. 2015. Peta Ketahanan dan Kerentanan Pangan Indonesia 2015. Jakarta (ID): DKP, Kementen, WFP

Fanzo J. 2014. Strengthening the engagement of food and health systems to improve nutrition security: Synthesis and overview of approaches to address malnutrition. Glob Food Sec 3(3-4):183-192. https:// doi.org/10.1016/j.gfs.2014.09.001.

[FAO] Food and Agriculture Organization $\mathrm{f}$ The United Nations. 1996. World Food Summit: Rome Declaration on World Food Security. Rome (IT): FAO.

[FAO] Food and Agriculture Organization of The United Nations. 2005. Voluntary Guidelines to Support the Progressive Realization of the Right to Adequate Food in the Context of National Food Security. Rome (IT): FAO.

[FAO] Food and Agriculture Organization of The United Nations. 2006. The Right to Food in Practice. Implementation at the National Level. Rome (IT): FAO.

[FAO] Food and Agriculture Organization of The United Nations. 2012. Coming to Terms with Terminology: Food Security, Nutrition Security, Food and Nutrition Security, Food and Nutrition Security, Report of the 39th session of the Committee on World Food Security (CFS). Rome (IT): FAO.

[FAO] Food and Agriculture Organization of The United Nations. 2014. Procedure for Monitoring The Right to Food. Right to Food Handbooks 5th. Rome (IT): FAO.

[FAO/IFAD/WFP] Food and Agriculture Organization of the United Nations, International Fund for Agricultural 
FNS evaluation based on outcome indicators in Indonesia

Development, World Food Programme. 2014. The State of food insecurity in the world 2014: Strengthening the enabling environment for food security and nutrition. Rome (IT): FAO.

Godfray HCJ, Garnett T. 2014. Food security and sustainable intensification. Philosophical Transaction of the Royal Society B: Biological Sciences 369(1639):1-10. https://doi.org/10.1098/rstb.2012.0273.

[IFPRI] International Food Policy Research Institute. 2014. Global Hunger Index: The Challenge of Hidden Hunger. Washington DC (USA): IFPRI.

Ismail Z, Kartasurya MI, Mawarni A. 2016. Analisis implementasi program penanggulangan gizi buruk di puskesmas wilayah kerja dinas kesehatan Kota Sorong Provinsi Papua Barat. Jurnal Manajemen Kesehatan Indonesia 4(1):20-26. https:// doi.org/10.14710/jmki.4.1.2016.20-26.

Keino S, Plasqui G, de Borne BV. 2014. Household food insecurity access: A predictor of overweight and underweight among Kenyan women. Agric Food Secur 3(2):1-8. https://doi.org/10.1186/20487010-3-2.

[MoH RI] Ministry of Health Republic of Indonesia. 2002. Keputusan Menteri Kesehatan Nomor:920/Menkes/SK/ VIII/2002 Tentang Klasifikasi Status Gizi Anak Bawah Lima Tahun (BALITA). Jakarta (ID): MoH RI.

[MoH RI] Ministry of Health Republic of Indonesia. 2012. Profil Kesehatan Indonesia 2012. Jakarta (ID): MoH RI.

[MoH RI] Ministry of Health Republic of Indonesia. 2013a. Profil Kesehatan Indonesia. Jakarta (ID): MoH RI.

[MoH RI] Ministry of Health Republic of Indonesia. 2013b. Riset Kesehatan Dasar 2013. Jakarta (ID): MoH RI.

Maricic M, Bulajic M, Dobrota M, Jeremic V. Redesigning the global food security index: A multivariate composite i-distance indikator approach. International Journal of Food and Agricultural Economics 4(1): 69-86. doi: 10.22004/ag.econ.231376.

$\mathrm{Ng}$ Marie, Fleming T, Robinson M, Thomson B, Graetz N, Margono C, Mullany Erin C, Biryukov S, Abbafati C, Abera SF et al. 2014. Global, regional, and national prevalence of overweight and obesity in children and adults during 1980-2013: A systematic analysis for the global burden of disease study 2013. Lancet 384 (9945):766-781. https://doi.org/10.1016/ S0140-6736(14)60460-8.

Nurhemi, Soekro SRI, Suryani G. 2014. Working paper no. 4 Pemetaan Ketahanan Pangan di Indonesia: Pendekatan TFP dan Indeks Ketahanan Pangan. Jakarta (ID): Bank Indonesia.

[OECD] Organization For Economic CoOperation And Development. 2008. Handbook on Contructing Composite Indicators: Methodology and User Guide. OECD

Palupi E, Sulaeman A, Ploeger A. 2013. World hunger, malnutrition and brain development of children. J Future of Food: Journal on Food, Agriculture and Society 1(2):46-56.

Pangaribowo EH, Gerber N, Torero M. 2013. Food and nutrition security indicators: A review. ZEF Working Paper Series 108. Boon, Germany: Center for Development Research (ZEF). Germany (DE): University of Bonn.

Santeramo FG. 2015. On the composite indikators for food security: Decisions matter! Food Rev Int 31(1):63-73. https://doi.org/10.10 80/87559129.2014.961076.

Supriyanto Y, Paramashanti BA, Astiti D. 2018. Berat badan lahir rendah berhubungan dengan kejadian stunting pada anak usia 6-23 bulan. Jurnal Gizi dan Dietetik Indonesia 5(1):23-30. http://dx.doi. org/10.21927/ijnd.2017.5(1).23-30.

Suryana A, Arifin B, Hardinsyah, Achadi EL, Atmawikarta A, Martianto D, Hermanto, Sastraatmadja E, Lukman AS, Darmawiredja MR et al. 2016. Kebijakan Strategis Rencana Aksi Pangan dan Gizi Tahun 2016-2019. Jakarta (ID): Sekretariat Dewan Ketahanan Pangan.

Susanty NM, Margawati A. 2012. Hubungan derajat stunting, asupan zat gizi dan sosial ekonomi rumah tangga dengan perkembangan motorik anak usia 2436 bulan di wilayah kerja Puskesmas Bugangan, Semarang. J Nutr College 1(1):327-336. https://doi.org/10.14710/ jnc.v1i1.736. 
Vidyarini et al.

Tono T, Juanda B, Barus B, Martianto D. 2016. Kerentanan pangan tingkat desa di Provinsi Nusa Tenggara Timur. J Gizi Pangan 11(3):227-236. https://doi.org/10.25182/ jgp.2016.11.3.\%25p.

Ulfani DH, Martianto D, Baliwati YF. 2011. Faktor-faktor sosial ekonomi dan kesehatan masyarakat kaitannya dengan masalah gizi underweight, stunting dan wasted di Indonesia: Pendekatan ekologi gizi. J Gizi Pangan 6(1):59-65. https://doi. org/10.25182/jgp.2011.6.1.59-65.

von Grebmer K, Bernstein J, Hossain N, Brown T, Prasai N, Yohannes Y, Towey O, Foley C, Patterson F, Sonntag A et al. 2017. Global Hunger Index: The Inequalities of Hunger. Washington DC (USA): International Food Policy Research Institute.
Warsini KT, Hadi H. Nurdiati DS. 2016. Riwayat KEK dan anemia pada ibu hamil tidak berhubungan dengan kejadian stunting pada anak usia 6-23 bulan di Kecamatan Sedayu, Bantul, Yogyakarta. Jurnal Gizi dan Dietetik Indonesia 4(1):29-40.

[WHO] World Health Organization. 2010. Nutrition Landscape Information System (NLIS) Country Profile Indicators. Geneva (CH): WHO.

[WHO] World Health Organization 2015. Nutrition targets and indicators for the Post-2015 sustainable development goals accountability for the measurement of results in nutrition: A technical note. http://www.unscn.org/files/Publications/ Post 2015 Nutrition Targets and Indicators_final_March_2015_website_. pdf [Accessed 2nd December 2016]. 